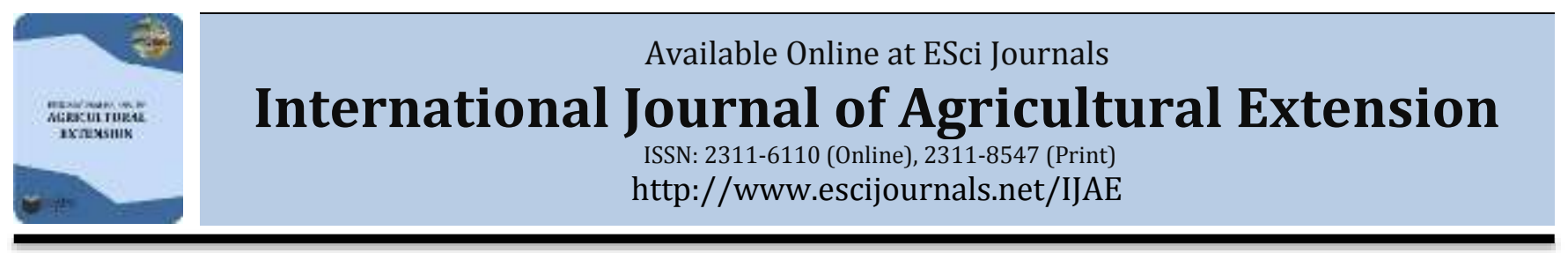

\title{
FACTORS PERCEIVED TO INFLUENCE THE ADOPTION OF IMPROVED TECHNOLOGIES IN ARABLE FARMING IN THE SOUTHERN DISTRICT OF BOTSWANA
}

\author{
${ }^{a}$ Gagoitsiwe Moremedi, aKeba Hulela*, bTonic L. Maruatona \\ a Department of Agricultural Economics, Education and Extension, Botswana University of Agriculture and Natural \\ Resources. \\ ${ }^{b}$ Department of Adult Education, University of Botswana.
}

\begin{abstract}
A B S T R A C T
The purpose of this study was to investigate the perceptions of farmers regarding the adoption of new technologies in arable farming. This was a phenomenological qualitative study conducted in the southern district of Botswana. Data was gathered from 16 purposively selected arable farmers who adopted improved technologies to enhance productivity in arable agriculture. Semi-structured interviews on a face to face survey and personal records kept upon visit to farms were used to collect data. Both qualitative and quantitative sets of data were gathered during visit to the farms. The study found that the majority of the arable farmers inherited their farms from their parents and were influenced by parental role models, individual family members, credit availability of social interactions, commercialisation as well as extension training workshops to adopt improved technologies. This study has shown that farmers' perceptions regarding improved technologies to enhance productivity in arable farming are important and influenced by several factors revealed in this study. The theoretical implication of improved technologies in arable farming imply that the when technology is adopted it increases productivity in arable agriculture as compared to no technology adoption and the adoption is influenced by how farmers perceive its benefits. This study being one of the few studies in the district will add value to the importance of technology in agriculture and increase knowledge about technology to address food security issues.
\end{abstract}

Keywords: Adoption, agricultural technology, qualitative research, phenomenological paradigm.

\section{INTRODUCTION}

The study was conducted in the southern district of Botswana to investigate the perceptions of farmers regarding the adoption of new technologies in arable farming. The southern district is one of the ten agricultural districts in the country which has continuously received modern technologies in order to improve yield, through the Ministry of Agricultural Development and Food Security formerly known as Ministry of Agriculture, particularly in arable farming since the country gained independence in 1966. This study singled out the district \# 9 (Figure 1) specifically to investigate the factors influencing the adoption of the improved technologies by arable farmers. The district

* Corresponding Author:

Email: khulela@buan.ac.bw

(C) 2018 ESci Journals Publishing. All rights reserved. predominantly has majority of the farmers being engaged in arable agriculture than other parts of the country. In the southern district farmers have strategically commercialised their farming and have been consistently receiving improved technologies. According to UNDP (2012) farming in Botswana comprises both arable and livestock, and it is mainly traditional (subsistence than commercial agriculture. This is so because, majority of the farmers in Botswana are practicing mainly traditional agriculture without the adoption of improved technologies and the government through agricultural extension of the Ministry of Agricultural Development and Food Security is on the lookout to upgrade and turn around the farming sector into a commercial entity (UNDP, 2012). Figure 1 shows the map of Botswana depicting the eight districts where both arable and pastoral farming occur. That global 
population is projected to reach 9.8 billion by the year 2050, experts all over the globe are beginning to wonder how countries will be able to feed their increasing populations (Faisal \& Parveen. 2004, Godfray et al., 2010, Schmidhuber \& Tubiello. 2007). Although increasing the allocations for farm land seems to be the most logical solution, transforming natural habitats into farm land can have disastrous consequences in the environment (Clay, 2004). With this in mind, a better solution would be to maximize the productivity of current farm lands. To accomplish this, farmers would need to manage their land and water as efficiently as possible. Unfortunately, water scarcity and extreme weather conditions lead to uncertainties that force farmers to make extreme decisions, decisions that can damage the fertility of the land (Nelson et al., 2010). As a result of this, several conservation agencies have been established around the country to help farmers.

\section{Zambia}

Namibia

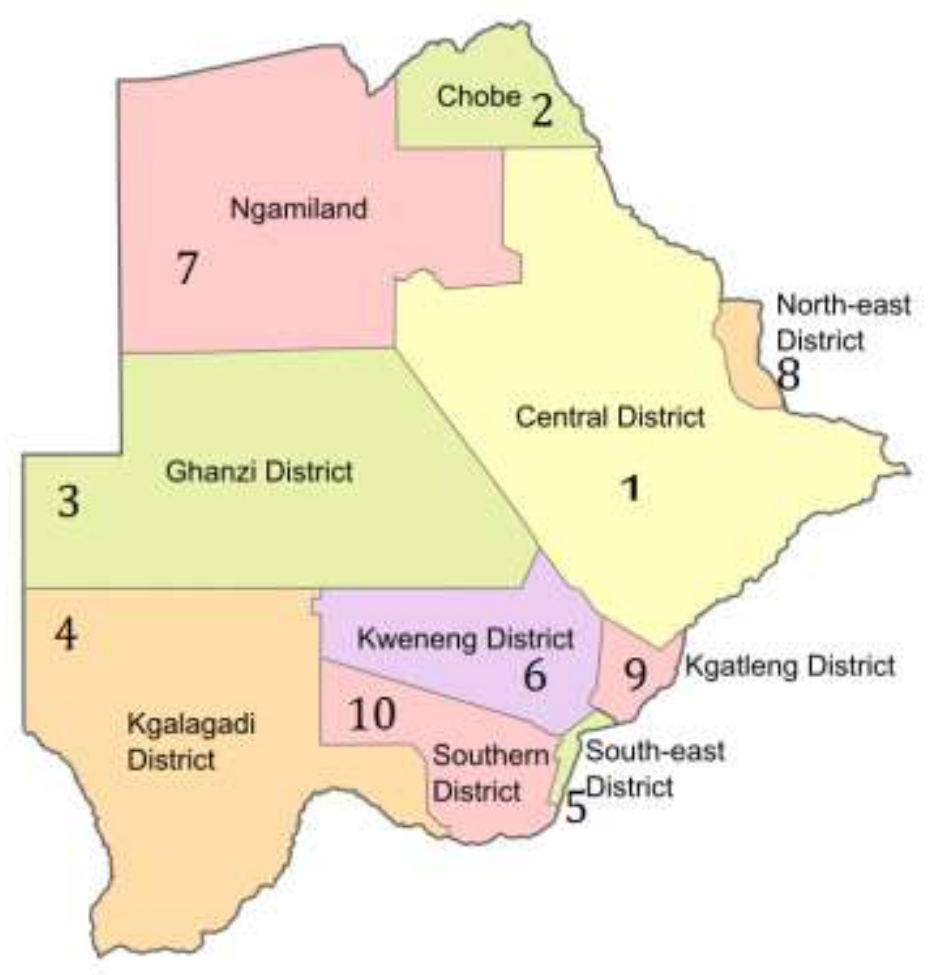

Zimbabwe

South Africa

Figure 1. The map of Botswana with 10 districts 1- 10.

Source: https://en.wikipedia.org/wiki/Districts_of_Botswana

According to Namonje-Kapembwa and Chapoto (2016), the growth of agricultural productivity in Sub-Saharan Africa has remained low over many decades despite the effort made to introduce improved technologies. The authors further stated that the use of improved technologies such as modern seed varieties and other technologies are indispensable for farmers to increase their crop harvest so as to improve people's livelihoods. In Botswana, Mbulawa (2017) stated that, despite the numerous programs initiated by the government, the arable sub-sector has not been doing well since the country gained independence. For example, in the mid1980s the Arable Lands Development Program (ALDEP) a project funded by IFAD and the Government of Botswana was introduced to help in raising the production of food grains by small farmers and make the economy less dependent on imported food (Republic of Botswana, 2006). In the 1990s the Accelerated Rain fed Arable Programme (ARAP) was introduced, and according to Seleka (1998), this programme effectively helped to increase cultivated area by approximately $27 \%$, output by $120 \%$ and yields by $74 \%$ in traditional arable agriculture. The two programs were followed by the National Master Plan for Arable Agricultural and Dairy Development (NAMPAADD) which was designed with the intention to reduce the country's dependency 
on food imports by making arable and dairy farming attractive and profitable (Ministry of Agriculture, 2012). The Ministry of Agriculture (2012) stated that the objective of the NAMPAADD program was transforming the traditional farming practices to the commercialized one. Previous studies have shown that the adoption of improved technologies in agriculture has enhanced farming efficiency and has the potential to decrease poverty (Agwu, 2004; Govindaraj et al., 2009; Eneji et al, 2012). In Botswana, there is minimal research to date on factors that influence the adoption of improved technologies particularly in arable agriculture, hence, the need to undertake the study. The study investigated factors perceived to influence the adoption of improved technologies in arable farming in the southern district of Botswana. Specifically, the research analysed personal characteristics of farmer participants, technologies adopted to enhance productivity and factors perceived to influence technology adoption.

Literature Review: According to Moyo et al. (2015) agriculture remain an important and vital sector for economic development in Africa even though its contributions vary from one country to the other. In Botswana, agriculture contributes less than three percent to the GDP (Republic of Botswana, 2009). According to Oladele (2005) the adoption of improved technologies by arable farmers and extensionists has been the topic of interest since the 1960s and 1970s. Adoption of improved technologies refers to a number of things which include among others one's decision to apply an innovation or one's decision to adopt some scientifically proven knowledge and information in agriculture to enhance productivity (Oladele, 2005). The author further indicated that there are several factors which influences technological adoption and these may be economic, social and physical.

The importance of adopting improved technologies by arable farmers cannot be overemphasized as the impact of new improved seed varieties, planting methods and adoption of improved strategies showed some positive impact on households' food security (Mwangi \& Kariuki, 2015). In conformity, the study by Kinuthia \& Mabaya (2017) revealed that those using improved technologies in Uganda tend to be different from those that did not adopt it, in that, they had an improved standard of living. It is also believed that the adoption of improved technologies has contributed positively to improved agricultural productivity in developing nations. Miah \&
Oma (2012) stated that, worldwide, nations are integrating various forms of technology, including devices such as computers, radios, cellular phones, televisions, newspapers, and the internet into their daily lives because technology has contributed immensely to the development of agriculture.

In this situation, agricultural extension plays a major role in transferring technology to farmers. Msuya et al. (2017) noted that despite all challenges faced by agricultural extension sector in performing their functions in many African countries, extension is still the key to development as it brings to the farming community some new technologies for adoption. It is through extension service that technologies and information on productivity, incomes, and standard of living are taken to farmers.

\section{METHODOLOGY}

Semi-structured interview was used to collect information from the farmers in their natural world. Going into this world, Rossman \& Rallis (2003) offered the researcher, the opportunity to collect information from purposely selected farmers who know about the adoption of improved technologies and to also see activities and events related to the phenomenon under investigation. In this study, the researcher accumulated sufficient information through observation and interaction with farmers. In addition, the principal investigator gathered data using tape-recorders to get audio and also observed farmers working in farms as recorded.

The study targeted thirty-four (34) pilot farmers in the southern district of Botswana who were registered in the NAMPAADD office in the Ministry of Agricultural Development and Food Security. This group of arable farmers have adopted improved technologies and are regarded as emerging commercial farmers by the Ministry. Sixteen (16) out of thirty-four (34) farmers were purposively selected to participate in the study. The criteria for selecting farmer participants was based on availability and/or willingness of farmers to be interviewed, and those owning at least $\geq 16$ ha of land, farmers who owned one or more planting machinery, farmers who use or apply organic fertilizers (kraal and compost manure) to improve soil fertility, and have adopted improved farming methods (technologies), usage of herbicides and insecticides to control weeds and pests respectively. The participants were also selected because they have attended more than 3 
extension training workshops conducted by agricultural extension agents to improve knowledge and skills. The data analysis enabled the researcher to generate codes for coding using the axial coding whereby data were categorised and made sense out of the phenomenon studied. The analysis was based on making meaning of the responses gathered from the farmers based on the conditions that gave rise to it such as the context in which it is embedded, the strategies that people use to manage the adoption or to carry it out and the consequences of those strategies. Thus, the analysis was based on Kleiman (2004) descriptions which involve reading out the transcript twice or more in order to get meaning and sense out of the data gathered, followed by identifying some units and integrating the results. The study was approved by the Ministry of Agricultural Development and Food Security and validated by a committee of social scientist at the University of Botswana. The participants who agreed to participate in the study were asked to complete informed consent forms to show their agreement. The researchers were part of the tool for gathering data has shortcomings and biases that may have impacted on the study outcomes because of the researchers' subjectivity, personal attitudes, and beliefs about the technologies adopted.

\section{RESULTS AND DISCUSSION}

On the average, the demographics of farmer participants

Table 1. Farmers personal information.

\begin{tabular}{|c|c|c|}
\hline Personal attributes & Frequency & $\%$ \\
\hline \multicolumn{3}{|c|}{ Gender } \\
\hline Females & 1 & $6.25 \%$ \\
\hline Males & 15 & $93.75 \%$ \\
\hline \multicolumn{3}{|c|}{ Age range } \\
\hline $30-40$ years old & 2 & $12.50 \%$ \\
\hline $41-60$ years old & 8 & $50.00 \%$ \\
\hline 61 years and above & 6 & $37.50 \%$ \\
\hline \multicolumn{3}{|c|}{ Education } \\
\hline College and university & 8 & $50.00 \%$ \\
\hline Primary to seconday & 6 & $37.50 \%$ \\
\hline Non-formal education & 2 & $12.50 \%$ \\
\hline \multicolumn{3}{|c|}{ Previous job } \\
\hline Ministry of agriculture & 3 & $38.75 \%$ \\
\hline Ministry of Education & 2 & $12.50 \%$ \\
\hline South Africa Mines & 3 & $18.75 \%$ \\
\hline Botswana Mines & 1 & $06.25 \%$ \\
\hline \multicolumn{3}{|c|}{ What motivated you to farm? } \\
\hline Family farming & 14 & $87.50 \%$ \\
\hline
\end{tabular}

constituted six percent (6\%) woman, $12 \%$ farmers were in the mid-30s and have worked with parents on family farms and on the demise of their parents, inherited such farms, 50\% had college and university education, and $\geq$ $40 \%$ have primary to secondary education, while $12.5 \%$ have no formal education. By ordinary standard, the participating farmers were all able to read and write. All farmer participants indicated having adopted technologies; row planting, use of fertilizers, use of certified seeds, pest control measures and weed control strategies. Farmers also indicated having adopted advanced agricultural infrastructure that includes, drilled boreholes, irrigation facilities, machinery, computers, mobile phones, and storage facilities. The findings concur with four factors pointed out by Moyo et al. (2015) in their study on transforming agriculture in Africa. The analysis also showed that $38.75 \%$ of farmers had worked at Ministry of agriculture as agricultural demonstrators while $12.5 \%$ worked for education, $18.75 \%$ worked in South Africa mines and only 6\% worked in Botswana mines. Others migrated from other parts of the country to buy farms to start farming. Table 1 also shows that majority (88\%) of the farmers indicated that they were motivated into farming by their families. All farmer participants lived with their family members (wives, fathers, mothers, children and extended family members) who assisted on the farm. 
Int. J. Agr. Ext. 6(3). 2018. 193-202

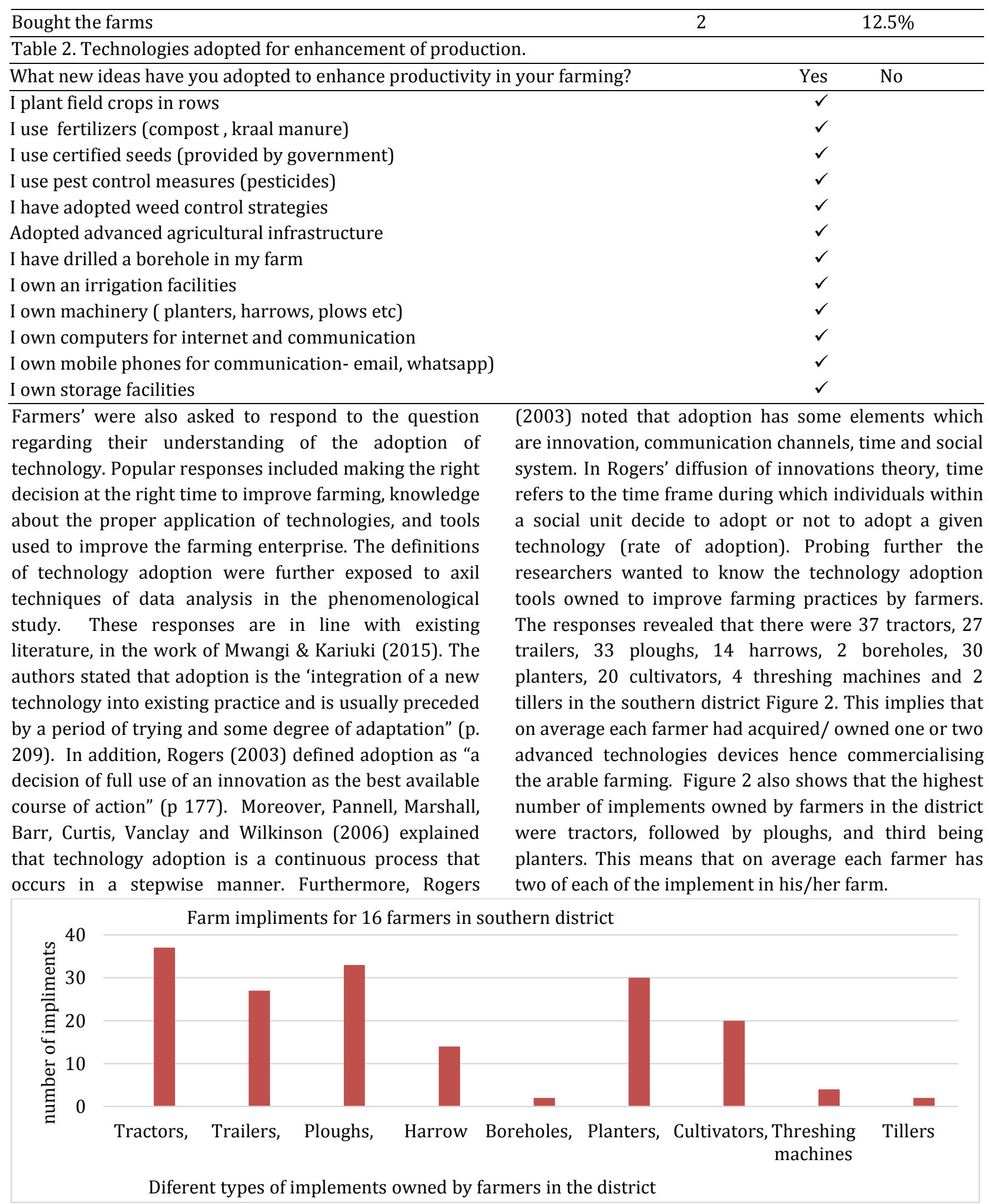

Figure 2. Data on advanced farm implements recorded among the 16 farm participants. 
Farmers were asked to describe the factors that influenced their decisions to adopt improved farming methods, devices and new farming ideas in their practices. A list of responses were gathered from farmers to include influence from parents, services provided by extension workers, income generation, change of life style, member to farmer organisations, rich farmer models, interactions with international farmers, support from credit facilities, reading farmers magazines, education and knowledge gained from workshops, and yield obtained. Other narrative statements gathered from farmers which tended to influence them to adopt technology were resource availability, government policies, and availability of market facilities as well as theories preached by extension advisory services. In an effort to analyse data on experiences lived by farmers in the southern district the narrative statements gathered through face to face survey were categorised into six themes. These are; (1) role modelled by parents and family members (2) social interactions (3) commercialisation (4) lessons from extension service providers (5) credit availability and (6) membership to organisations of farming (Farmers' Associations). In line with these results Kinyangi (2014) found that in a study conducted in Kenya, capital and credit facilities have positive and significant association on the adoption of agricultural technology.

The descriptions that follow are based on six themes that emerged from the responses gathered to include: First, role modelling a number of farmer respondents indicated that their parents were skillful farmers, which afforded them the opportunity to learn from them through observation. Some responses also indicated that the adopted and applied improved arable technologies and tools to enhance yield were as a result of role modelling by someone they admired and tried to imitate them hence they became adopters of improved technologies. For instance, as noted from the responses there were farmers who said 'my parents were into farming' 'I inherited my father's farm' 'farming is a family thing'. Furthermore, some said 'like father like son' 'I wanted to continue the legacy of my parents' 'This finding is supported by Bandura's theory of Social Cognitive Theory which posits that human conduct may be a result of observation, imitation, and modelling (Bandura, 1986). This can also be associated with the concept of scaffolding and reciprocal teaching (Polman, 2010) which provided effective strategies to access the zone of proximal development, providing those who are learning the opportunity to extend their current skills and knowledge on the phenomenon. The theory also takes into consideration the importance of culture, as developed over historical time within which those interactions are taking place between the parents and children (Cole, 2005; Daniels, 2005).

Second, the interactions with farmer adopters. A majority number of participants disclosed that their decision to adopt improved arable technologies were driven by informal interactions with advanced farmers who have used new technology to increase productivity. Participants explained that sharing information during informal open discussions at agricultural fairs, workshops organised by farmers and associations, Ministry of Agricultural Development and Food Security and at family gatherings offered them the opportunity to learn from technology adopters. In Uganda, Kasirye (2013) observed that learning from others was an important driver of agricultural technology adoption. Rogers (1995) has developed five variables which affected the adoption rate of any particular innovation. In this manner, Rogers is offering a scientific approach to understanding the rate of adoption to include 1) perceived attributes of innovations 2) type of innovation-decision, 3) communication channels, 4) nature of the social system, and; 5) extent of change agents' promotion efforts. Thus, influencing the adoption of new ideas, knowledge and skills.

Third, commercialisation of farming: The third category of themes point to a situation whereby farmer participants adopted technologies for the desire to make money and earn a living through farming. Participants pointed out that technology adoption provided an opportunity for increased crop yield, consequently increased farm income. For example, majority of the interviewees said, 'technology adoption is a means towards economic gain', 'towards marketing their produce' 'improved yield', 'addressing rural economy' 'improving farming from subsistence to business, 'commercialising agriculture'. All these phrases indicate the need to commercialise farming. To this end, Wiggins, Argwings-Kodheck et al. (2011) noted that commercialisation is about increasing engagement with markets which is part of the phrases gathered from farmers' responses. The authors posit that commercialisation entails increasing elements of crops and their products being destined for sale and therefore 
a means towards economic gain and raising the standard of living for farmers. This implies generating money through the sale of products and employment and meeting the requirements of life.

Fourth, extension advisory services: a good number of participants indicated that their interaction with extension staff influenced the decision to adopt improved farming methods. The extension advisory services have an extensive mandate to educate, train, disseminate information, and improve farmers' understanding and levels of technology adoption. Some of the farmers recalled how they have seen their own parents working with extension workers to gain information on modern farming methods. To this end, Arema et al. (2015) stated that agricultural extension is concerned with disseminating "new skills, new technologies, techniques of production in agriculture that will ultimately improve the living standard of target audience" (p. 14). The result is consistent with the work of Msuya et al (2017).

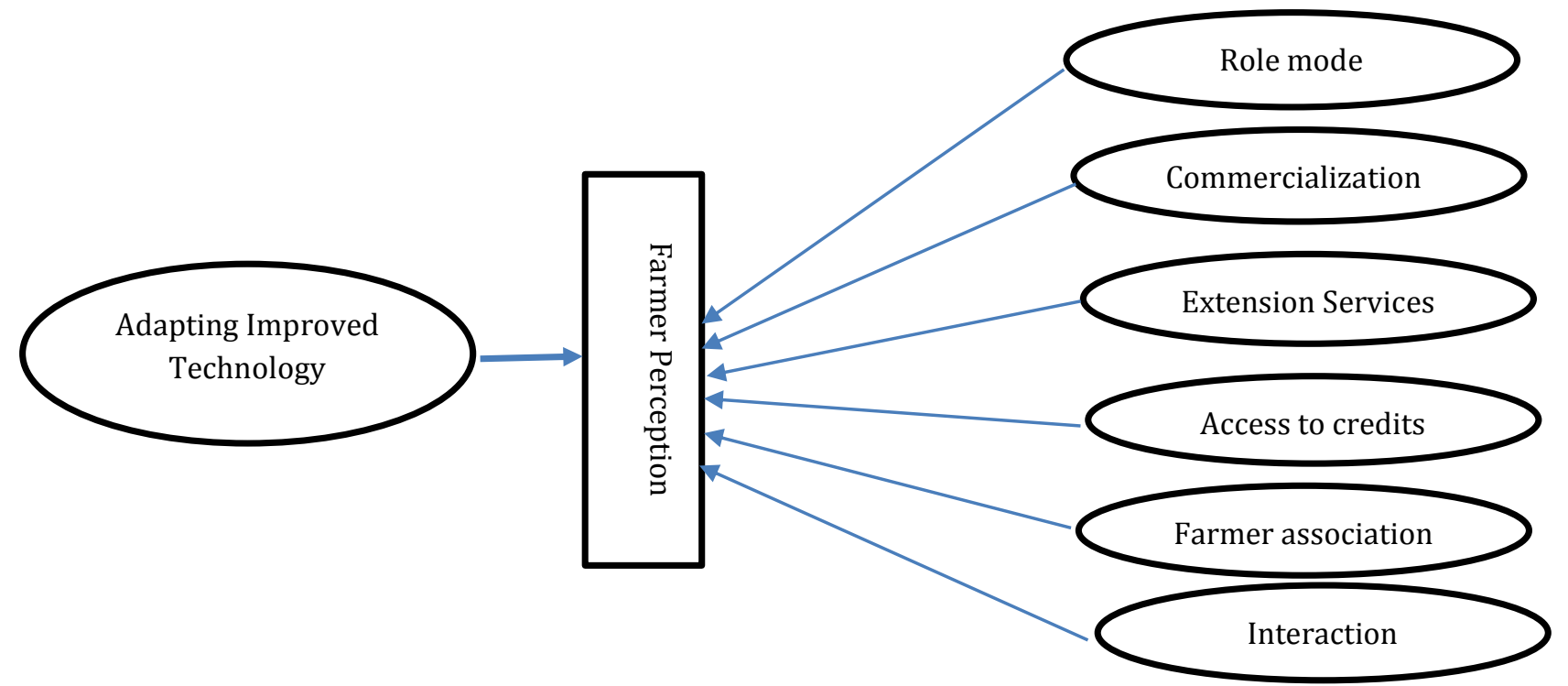

Figure 3. Farmers' perceptions of the factors influencing the technologies.

Fifth, membership to farmers' organisations. Some farmers were frank to share that their involvement with district farmers, agriculture fairs/ shows and seed growers' associations operating in the region and nationwide provided an opportunity for them to learn more about existing technologies. Farmer associations are non-profit making organisations providing leadership skills and training opportunity for farmers. Their goal is to bring farmers together in a region or category of farming. For example, Mwaura (2014) reported that the Uganda farmers who were members of a farmer group were able to adopt improved technologies and as a result, they achieved higher cassava and banana yields. In addition, Uwaegbuonu (2010) discovered that in Nigeria, well conceptualised and supported farmers group facilitated the adoption of improved farming methods.

Sixth, access to credit. Participant respondents explained that access and availability of credit is a critical issue in the adoption process because the implementation or application of modern farming methods is costly. Farmer participants were in consensus that the cost of farm inputs such as fertilizers, seeds, advanced machinery, and equipment is very high. Farmers opined that improved access to credit enhanced their ability to buy the required farm inputs, machinery, and equipment. Furthermore, access to credits enabled them to offset transport costs associated with transporting inputs from suppliers to the farm and transporting farm produce to the markets. To this end, a study in Kenya by Mwangi \& Kariuki (2015) found that the key determinants for agricultural technology adoption include, credit accessibility. Challa \& Tilahun (2014) alluded to the fact that in Ethiopia access to credits in commercial banks was one of the factors that influenced farmers in West Wollega to adopt modern agricultural technologies. Similarly, in India Rao, Samuel, Kumar, Raju et al. (2014) observed that access to credit allowed farmers to adopt technologies and this increased farmers "net returns by 20- 84 percent" (p. 187). Based on the six thematic areas, 
farmers' adoption of technology is influenced by several factors that include parental role models, individual family members, social interactions, commercialisation, and lessons from extension service providers, credit availability and membership to professional organisations on farming. Figure 3 diagrammatize the factors perceived to have influenced the adoption of improved technologies in their farming. The diagram further illustrates that farmers were able to see and interpreted the need for technology adoption.

The study investigated how farmer participants perceived improved technologies in arable farming. The participants were asked 'how do you perceive enhanced technologies in arable agriculture?' Farmers were positive as several response statements such as 'it increases production', technology enhances food security', increase in crop yield, and overcoming of pest attack were gathered. Farmers' responses showed that improved technologies in agriculture referred to adopting practices such as application of fertilizers, pest and weed control measures, use of tools like machinery and knowledge from extension workers (Uzonna and Qijie, 2013). Responses such as these showed that farmers were positive and interested in the adoption of new farming practices to increase yield. The results are supported by Busari, Idris-Adeniyi and Ajewole (2015) who measured the level of adoption of improved practices among arable crop farmers in Nigeria but found that majority were still using low level improved technologies and the few who adopted improved technologies significantly increased their crop yields.

\section{CONCLUSION AND RECOMMENDATIONS}

The study established that farmers used various sources to acquire information on improved technologies. These sources included extension advisory services, farmer adopters and parents. The study, therefore, concluded that education of a farmer and exposure to improved systems of farming enhanced individual's rate of adoption of technology in arable farming. Furthermore, the study concluded that families, farmer organisations and extension service are a critical mechanism for technology dissemination and adoption. In addition, the study found all the adopters owned improved farming machinery and equipment.

The study, therefore concluded that ownership of appropriate farming equipment facilitated technology adoption to enhance farmers' capacity to earn money and sustain their livelihoods. Finally, the study concluded that technology adoption in the Southern District of Botswana is associated with certain influences as illustrated in Figure 3.

The study further concluded that farmer participants have a broad understanding of the concept of adoption. Farmers' understanding of adoption does not only entail making decisions to put in practice an innovation and making constant reviews to effect modifications as necessary, but it means planning and making preparations to undertake requisite operations at the most appropriate time.

The study, therefore, recommends that the government should consider guaranteeing agricultural loans acquired from all credit facilities including commercial loans. The study has also established that out of the sixteen studied participants, there was only one female adopter, this implies that all others [if any] did not meet the criteria set for this research study. It is therefore recommended that there be another study to explore the issue of female farmers' participation in agriculture and specifically in the adoption of improved technologies. A comprehensive study is needed to interrogate the extent to which these factors have contributed to technology adoption in other districts of the country.

\section{REFERENCES}

Agwu A. E (2004). Factors influencing adoption of improved cowpea production technologies in Nigeria. Journal of International Agricultural Extension and Education, 11(1), 81-89.

Anney, V.N. (2014) Ensuring the Quality of the Findings of Qualitative Research: Looking at Trustworthiness Criteria. Journal of Emerging Trends in Educational Research and Policy Studies (JETERAPS), 5(2), 272-281.

Aremu, P.A., Kolo, I.N., Gana, A.K. \& Adelere, F.A. (2015). The crucial role of extension workers in agricultural technologies transfer and adoption. Global Advanced Research Journal of Food Science and Technology, 4(2), 14-18.

Bandura, A. (1986). Social foundations of thought and action: A social cognitive theory. Englewood Cliffs, NJ: Prentice-Hall, Inc.

Busari, A O Idris-Adeniyi K. M \& Ajewole O. P. (2015). Adoption of improved farming practices among arable crop farmers in Iwo Zone of Osun State Agricultural Development Programme. Journal of Agricultural Economics, Extension and Rural Development, 2(1), 240-243. 
Challa, M., \& Tilahun, U. (2014). Determinants and impacts of modern agricultural technology adoption in West Wollega: The case of Gulliso District. Journal of Biology, Agriculture and Healthcare, 4(20), 63-77.

Cole, M. (2005). Cultural-historical activity theory in family of socio-cultural approaches. International Society for the Study of Behavioural Development Newsletter, 47(1), 14.

Creswell, J.W. (2012). Qualitative inquiry and research design: Choosing among five traditions. Thousand Oaks, CA: Sage Publications.

Eneji, M. A., Song Weiping, S.and Ushie, O.S. (2012). Benefits of agricultural technology innovation capacity to peasant farmers in rural poor areas: The case of DBN-Group, China. International Journal of Development and Sustainability Online ISSN: 2186-8662 www.isdsnet.com/ijds , 1(2), 145-170.

Govindaraj, G., Kumar, G.D.K S \& Basu M.S. (2009). Benefits of Improved Groundnut Technologies to Resource-poor Farmers: A Participatory Approach1 Agricultural Economics Research Review, 22, 355-360.

Kasirye I (2013) Constraints to Agricultural Technology Adoption in Uganda: Evidence from the 2005/06-2009/10 Uganda National Panel Survey. Research Series No. 102.

Kasirye, I. (2010). Constraints to agricultural technology adoption in Uganda from 2005/06-2009/10 survey. Economic Research Centre, Kampala: Uganda.

Kinuthia, B. K \& Mabaya, E. (2017). The Impact of Agriculture Technology Adoption on Farmers' Welfare in Uganda and Tanzania. Pep policy brief, partnership for economic policy number, 163.

Kinyangi, A. A. (2014). Factors influencing the adoption of agricultural technology among smallholder farmers in Kakamega north sub-county, Kenya. A research project submitted in partial fulfilment of the requirements for the award of the degree of Master of Arts in project planning and management of the University of Nairobi.

Kleiman, S. (2004). What is the nature of nurse practitioners' lived experiences interacting with patients? Journal of the American Academy of Nurse Practitioners, 16, 263-269.

Lai P. C (2017). The literature review of technology adoption models and theories for the novelty technology. Journal of Information Systems and Technology Management, 14(1), 21-38.

Mbulawa, S. (2016). Accelerating agricultural productivity to enhance economic growth in Botswana. Current Research in Agricultural Sciences, 4(1), 14-31.

Miah, M. \& Omar A. (2012) Technology Advancement in developing countries during Digital Age Volume, International Journal of Science and Applied Information Technology, 1(1), 30-38.

Msuya, C.P., Festus K. Annor-Frempong, A., Magheni, M.N., Agunga, R.,Igodan, C.,. Ladele A.A., Hulela, K., Tselaesele, N.M., Msatilomo, H., Chowa, C., Zwane, E., Miiro, R., Bukeyn, C., Kima, L.A., Meliko, M., Ndiaye, A. (2017). The role of agricultural extension in Africa's development, the importance of extension workers and the need for change. International Journal of Agricultural Extension, 5(1), 59-70.

Mwangi, M., \& Kariuki, S. (2015). Factors determining adoption of new agricultural technology by smallholder farmers in developing countries. Journal of Economics and Sustainable Development, 6(5), 208-216.

Mwaura, F. (2014). Effect of farmer group membership on agricultural technology adoption and crop productivity in Uganda. African Crop Science Journal, 12(4), 917-927.

Moyo, J, M., Bah, E.M \& Verdier-Chouchane, A. (2015). Chapter 2.1: Transforming Africa's Agriculture to Improve Competitiveness: African Development Bank. http://www3.weforum.org/docs/WEF_ACR_20 15/ACR_Chapter2.1_2015.pdf

National Aeronautics and Space Administration Office (1977). The benefits of improved' technologies in agricultural aviation n78-11890 (nasa-cr156638 ) the benefits of improved ' technologies in agricultural aviation (econ, inc., San Jose, Calif.) $247 \mathrm{p} \mathrm{hc} \mathrm{all/mf} \mathrm{a01} \mathrm{cscl} \mathrm{02c}$ unclas G3/85 53355. Prepared For National Aeronautics And Space Administration Office of Aeronautics and Space Technology July 1977. 
https://ntrs.nasa.gov/archive/nasa/casi.ntrs.na sa.gov/19780003947.pdf

Namonje-Kapembwa T. \& Chapoto A. (2016). Improved Agricultural Technology Adoption in Zambia: Are Women Farmers Being Left Behind? Indaba Agricultural Policy Research Institute (IAPRI).

Oladele, O.I. (2005). A tobit analysis of propensity to discontinue adoption of agricultural technology among farmers in south-western Nigeria. Journal of European Agriculture, 6(3), 249-254.

Pannell, D.J., Marshall, G.R., Barr, N.,Curtis, A., Vanclay, F., \& Wilkinson, R. (2006). Understanding and promoting adoption of conservation practices by rural holders. Australian Journal of Experimental Agriculture, 46(11), 1407-1424.

Polman, J. L. (2010). The zone of proximal identity development in apprenticeship1 learning La zona de desarrollo próximo de la identidad en entornos de aprendizaje de oficios. Revista de Educación, 353, 129-155.

Rao, C.A., Samuel, J., Kumar, S., Raju, B.M.K., Dupdal, R. \& Venkateswarlu, B. (2014). Role of technology and credit in improving farm incomes in rainfed regions in Andkra Pradesh. Agricultural Economics Research Review Journal, 27(20), 187-198.

Republic of Botswana (2012) Ministry of Agriculture: National Master Plan for the Arable Agriculture and Dairy Development (NAMPAADD) implementation guidelines NAMPAAD Guidelines
Rogers, E.M. (2003). Diffusion of innovations. London: Macmillan Publishers.

Rogers E. M. (1995). Diffusion of Innovations Fourth Ed. The Free Press New York. Available o at https://www.d.umn.edu/ /rochfor/ireland/dif-of-inch06.pdf

Rossman, G.B., \& Rallis, S.F. (2003). Learning in the field: An introduction to qualitative research. 2nd Ed. Thousand Oaks, CA: Sage Publications Inc.

Seleka B. T. (1998). The performance of Botswana's traditional arable agriculture: growth rates and the impact of the accelerated rainfed arable programme (ARAP). Journal of Agricultural Economics, 20, 121-133.

UNDP (2012) Botswana Agriculture Sector Policy Brief, (2012). Agriculture and Food Security Policy Brief Reflecting on the Challenges of Attaining a Green Economy1 for Botswana.

Uwaegbuonu 0. I. (2010) Determinants of Adoption of New Technologies and the Role of Credit in the Production of Rice in Benue State, Nigeria, Agricultural Journal, 5(4), 264-268.

Uzonna, U.R. \& Qijie G. (2013). Effect of Extension Programs on Adoption of Improved Farm Practices by Farmers in Adana, Southern Turkey. Journal of Biology, Agriculture and Healthcare, 3(1), 15.

Wiggins, S., Argwings-Kodhek, G., Leavy, J., \& Poulton, C. (2011). Small farm commercialisation in Africa: Reviewing the issues. Future Agricultures Consortium, Research Paper. 